\title{
Is the Implementation of the New Vocational High School Curriculum Better than the Implementation of the Previous Curriculum?
}

\author{
Edy Supriyadi, Yuwono Indro Hatmojo, Faranita Surwi \\ Faculty of Engineering, Universitas Negeri Yogyakarta, \\ Yogyakarta, Indonesia \\ edy_via@yahoo.com
}

\begin{abstract}
The objective of this study was to determine how K-13 of Vocational High School was implemented, and how far this new curriculum implementation was better than the previous curriculum. The research respondents were Vocational High School teachers in the Special Province of Yogyakarta Indonesia. The data collection techniques used questionnaires, interviews, and observations. The results of the data analysis showed that in general, the implementation of K-13 in Vocational High Schools was not conducted appropriately, and did not achieve the desired results. K-13 framework and contents did not fully aligned with the schools' goals, the requirements of the world of work, and the needs of the community. The supporting facilities, human resources, the process of learning and assessment, and the management of the curriculum implementation were not organized properly thus the expected results of the new curriculum implementation was not optimally achieved. The implementation of the new curriculum was not better than the previous one, both from the aspect of supporting resources, the implementation process, and the achievement
\end{abstract}

Keywords - curriculum evaluation; vocational high school

\section{INTRODUCTION}

Education at every level, including vocational high school (VHS) plays a very significant role to provide competent human resources at international level. Vocational education is designed to develop the learners' competence to become productive workers. Vocational education also emphasizes the experience of empirical practices, which is carried out in schools and the world of work [1]. The world of work requires highly skilled, flexible, adaptable and cooperative vocational graduates to accurately identify and solve problems, and have practical experience in the world of work [2].

In order to produce graduates who have a set of competencies as expected, every component of the education system in VHS should be accurately designed and organized. One of the main components in education is the curriculum. The curriculum used in VHS in Indonesia since 2006/2007 is curriculum 2006 (previous curriculum). In accordance with its development, in the academic year of 2013/2014 the ministry of education and culture of Indonesia set a new curriculum policy for elementary and secondary education, including for VHS, namely K-13 (new curriculum). It is aimed to improve the previous curriculum. Curriculum change is normal and necessary, not just in Indonesia but some countries also updates the curriculum in accordance with the markets' demands. Assessment and improvement of the curriculum is important to fit the needs of learners and the world of work (Manitoba education, 2013). However, the education systems in some countries do not have a structured curriculum assessment or evaluation system. The curriculum evaluation tends to be ad hoc, unplanned, depending on the political cycles, and response to specific problems with the government [3]. K-13 applied in VHS is a competency-based curriculum. Competency-based curriculum emphasizes the achievement of complex learning outcomes, including knowledge, skills, and attitudes. The curriculum principles are student-centered, and adaptive to the development of the student's needs, teachers, communities, and the world of work [4] thus, activities and learning environments, including facilities and infrastructure, should be designed to facilitate the students achieve and apply their competence in various situations in the community and the workplaces. Learning materials and learning implementation strategies should always be refined according to the competencies required by the workforce, namely current or anticipated future competency needs [5].

$\mathrm{K}-13$ is a curriculum developed to improve and balance the hard skills and soft skills in the aspects of knowledge, skills and attitudes. The implementation of this curriculum is conducted to improve the application of the previous curriculum. The government have plot several programs to prepare the K-13, which consists of developing books, instructional media, and teachers' training and mentoring. In relation to the implementation of K-13 in VHS, an assessment is conducted to analyze the suitability of the process and the achieved results in the implementation of the K-13. As the material to complete the discussion, an assessment of the implementation of the previous curriculum, i.e. the curriculum 2006 was also conducted. 


\section{THEORETICAL REVIEW}

\section{A. Vocational High Schools Curriculum}

There are several conceptions and definitions of the curriculum, namely as content, as a learning experience, as learning objectives, and as a lesson plan. Simply, the curriculum is a description of what, why, how and how well students should learn systematically as expected [6].

The VHS curriculum has its own characteristics and specifications that distinguishes it from other education subsystems. The main success of the VHS curriculum is not only measured by the achievement of learning outcomes in the form of graduation, but on the ability of graduates later in the world of work. A competent VHS graduate will be very beneficial not only for himself but also for the world of work, and the wider community [7]. In order to achieve the desired learning outcomes, the description of a curriculum that will be used should be determined [8].

The success of curriculum implementation in schools is influenced by several main factors, among others: teachers, learners, facilities and infrastructure, curriculum tools such as syllabus and lesson plans, learning resources and media, learning implementation, and assessment of learning outcomes. To determine how far the effectiveness of curriculum implementation, evaluation needs to be conducted. Evaluation of curriculum implementation at the educational unit level includes the study of curriculum preparation and management, improvement of educators and educational staffs, and general learning implementation. Evaluation of the results of curriculum implementation assess the achievement of graduate competency standards of each learner in the education unit.

The use of an evaluation model is tailored to the training objectives and conditions. For programs that are macro, comprehensive, broad and related to government programs, the appropriate model used is the evaluation model of context, input, process and product (CIPP) by Stufflebeam. In this model, program evaluation is classified into four dimensions, namely context, input, process, and product. These dimensions need to be assessed during the end of the curriculum development process or educational program.

\section{B. Components of Supporting Curriculum Implementation}

Quality of education includes the qualities of learners, learning environment, content, processes, and results. Learners are expected to be healthy, well-nourished and ready to participate and learn, and are supported in learning by their families and communities. The learning environment are supposed to be a healthy, safe, protective and gender-sensitive environment, and it should provide adequate resources and facilities. The content is reflected in the relevant curriculum and materials for the acquisition of basic skills, especially in the areas of literacy, numeracy and skills for life, and knowledge in areas such as gender, health, and nutrition. Effective learning process is important and strongly determines the learning outcomes. Outcomes that include knowledge, skills and attitudes are linked to national goals for education and positive participation in society.
Vocational teachers should have a standardized set of competencies. Teacher competencies in learning are characterized by accurate planning, meeting students' competency expectations, challenging learning activities, providing questions that lead students to master competencies, engaging students in self-evaluation and reflection [5]. Vocational school teachers are expected to master the field of study, and have the competence in learning so that they are able to carry out learning and to achieve expected results [9]

The development of the world of work, such as the use of machinery, software, and management systems requires teachers to constantly update their skills. High-quality vocational teachers should be passionate, dedicated, motivated, creative, positive thinking, empathic, trustworthy, demonstrate strong communication skills, master their fields, and master the implementation of learning, and assessment of learning outcomes.

Implementation of the curriculum will be conducted appropriately for achieving the expected results when it is supported by adequate facilities. Physical support facilities include land and buildings, classrooms, laboratories or workshops, machinery or equipment, materials and other related facilities. Education facilities in schools should be adjusted to the real conditions in the world of work. Completeness and maintenance of good facilities will support the effectiveness of learning, and improve the students' achievement. In the end, graduates are able to work in industry or other institutions, and contribute to the development of society and the world of work [2]

\section{Learning and Assessment}

Each educator in the educational unit is obliged to develop a complete and systematic Lesson Plan to accommodate interactive, inspirational, fun, challenging, efficient learning, to motivate learners to participate actively, and to provide sufficient space for initiative, creativity and independence. The talents, interests, and physical and psychological development of learners should also be considered. The plan consists of a series of activities that will be carried out, both by teachers and students in the learning process. Lesson plans for students with varied characteristics should be universal. It means it is aimed to improve access, and reduce learning barriers such as students' physical, linguistic, cultural, and socioeconomic constraints [10]. Materials should be delivered through various activities, such as discussion, reading, and presentation using multimedia. The teachers are expected to provide the students opportunities to demonstrate their understanding, through among others: tests, preparation of papers, presentations, or works according to their fields. In addition, it is necessary to use appropriate teaching methods, such as scientific approach, collaborative, problem-based learning, project-based learning, and other related approaches.

Vocational education lesson plans should be based on educational principles, in accordance with the learning outcomes to be achieved, the characteristics and needs of the development of students' knowledge and skills, materials. Students' activities are organized according to the results of the initial ability assessment of students, and related to student 
learning activities in the world of work (Internship / industrial practice).

Effective learning is learning that can improve students' competency achievement to support students' success in the future (Coe, Aloisi, Higgins and Major, 2014). The learning process is developed in accordance with the characteristics and objectives of the curriculum. Learning Processes in VHS should be organized in an interactive and fun atmosphere to motivate students to participate actively, in accordance with the talents, interests, and physical and psychological development of the learners. Every school should do learning planning, implementation of learning process and assessment of learning process to improve efficiency and effectiveness of the graduates' competency achievements. Assessment is a significant thing to be conducted, and integrated with learning activities.

Assessment is defined as systematic process of collecting, analyzing and interpreting information to determine the extent to which students have achieved the learning objectives, and the results are utilized by teachers and students to optimize the effectiveness of learning [11]. Assessment is designed and implemented by each teacher according to the subject.

Learning outcomes are a process of a person's effort to gain a whole new behavioral change as a result of his own experience in interaction with his environment. Learning outcomes are the ability in the form of students' behavior in the form of cognitive, affective and psychomotor after receiving the learning experience.

Learning outcomes can be attributed to changes in intelligence, skill, or ability of a person, in which the process of intelligence takes place step by step. Learning outcomes are realized in five abilities: intellectual skills, cognitive strategies, verbal information, motor skills, and attitudes. Learning outcomes are a measure of student success in learning. Learning outcomes obtained with a set of tests and test results will provide information on the level of mastery of learners. Learning outcomes achieved by a person in the learning effort are expressed in the Report on Learning Outcomes.

Educators conduct an attitude competency assessment through observation, self-assessment, peer assessment by learners and journals. Assessment of knowledge competence is conducted through written tests, oral tests, and assignments. Skills competency assessment is conducted through performance appraisal, an assessment that requires learners to demonstrate a certain competence using practice tests, projects, and portfolio assessments.

Assessment of learning outcomes of learners in VHS should be able to function effectively, which can provide sufficient information about the quality and quantity to meet the stakeholder information and decision-making needs in support of improving the quality of education and students' learning outcomes. Assessment should be objective, integrated, focused on learning and development, motivating, and directing students to learn according to their learning styles, as well as informative and beneficial to all stakeholders [8]

Utilization of assessment results as feedback is an important part of the learning cycle. Feedback from assessment results is often not used properly, either by teachers or students. Students are still confused by the teacher's feedback, even embarrassing him. In addition, students sometimes do not receive guidance on how to use feedback to improve subsequent performance [12].

\section{METHOD}

This assessment focuses on the implementation of the VHS curriculum on Electricity Skills Programs. The main data source is the teachers from 10 Electricity Skills Programs at VHS in the Special Province of Yogyakarta Indonesia. The data collection used questionnaires, observations, document analysis, and interviews. The data obtained were analyzed descriptively according to the research problem.

\section{RESULTS AND DISCUSSION}

\section{A. Curriculum Implementation in the Aspects of Context}

Compliance curriculum in VHS viewed from the aspect of Context consists of five indicators, namely the suitability of curriculum implementation with: (1) the purpose of the school; (2) the community needs; (3) the needs of the world of work; (4) the development of Science and Technology; (5) the developmental condition of learners.

The results of data analysis from the VHS teachers as the respondents showed that in general the implementation of the curriculum 2006 from the aspect of Context is acceptable, while the implementation of K-13 is classified as good. The replacement of the curriculum 2006 to K-13 is appropriate when it is viewed from the context aspects.

Table 1 identifies the appropriateness of the implementation of the curriculum 2006 and the K-13 related to the needs of the community and the world of work which are classified as fair.

This needs serious attention, as the purpose of vocational education should lead to the needs of society and the world of work. This non-compliance will result in the absorption of graduates of vocational education in the world of work which is not optimal. As a result, many graduates will become unemployed. According to the data from the Central Bureau of Statistics [13], the number of VHS graduates each year who are not absorbed in the world of work or unemployment is the second largest after high school graduates. Unemployed VHS graduates in 2014, 2015 and 2015 were 1.332.521, 1.569.690, and 1.520 .549 respectively. If there is not adjustment of objectives and content of K-13 that leads to the needs of society and the world of work, the number of graduates of vocational schools that are not absorbed by the workforce will increase. Whereas according to Presidential Instruction No. 9 of 2016 [14], the President specifically designs programs to perfect and align the VHS curriculum with competency according to the requirements of VHS graduate users.

The school vision and mission and the structure of K-13 needs to be synchronized. The synergy of school vision and mission will affect all school citizens, including leaders, teachers, and employees in performing their duties. Ideally, all school residents have the same vision and mission in the 
TABLE I. IMPLEMENTATION OF CURRICULUM IN THE ASPECTS OF CONTEXT

\begin{tabular}{|c|c|c|c|c|c|c|c|}
\hline \multirow{2}{*}{ Curriculum } & \multicolumn{6}{|c|}{ The Percentage of Conformity of Curriculum Implementation with: } & \multirow{2}{*}{ Category } \\
\hline & $\begin{array}{c}\text { The goals } \\
\text { of VHS } \\
(\%)\end{array}$ & $\begin{array}{c}\text { Community } \\
\text { Needs } \\
(\%)\end{array}$ & $\begin{array}{l}\text { The needs of } \\
\text { world of } \\
\text { work }(\%)\end{array}$ & $\begin{array}{l}\text { Development of } \\
\text { Science and } \\
\text { Technology }(\%)\end{array}$ & $\begin{array}{c}\text { Development of } \\
\text { learners }(\%)\end{array}$ & Context (\%) & \\
\hline $\begin{array}{l}\text { Curriculum } \\
2006\end{array}$ & $\begin{array}{c}70,40 \\
\text { (Good) }\end{array}$ & $\begin{array}{l}65,20 \\
\text { (Fair) }\end{array}$ & $\begin{array}{l}67,80 \\
\text { (Fair) }\end{array}$ & $\begin{array}{l}66,60 \\
\text { (Fair) }\end{array}$ & $\begin{array}{l}68,20 \\
\text { (Fair) }\end{array}$ & $\begin{array}{l}67,64 \\
\text { (Fair) }\end{array}$ & Fair \\
\hline $\mathrm{K}-13$ & $\begin{array}{c}68 \\
\text { (Fair) }\end{array}$ & $\begin{array}{l}67,60 \\
\text { (Fair) }\end{array}$ & $\begin{array}{l}68,80 \\
\text { (Fair) }\end{array}$ & $\begin{array}{c}75,10 \\
(\text { Good })\end{array}$ & $\begin{array}{c}74,30 \\
\text { (Good) }\end{array}$ & $\begin{array}{c}70,76 \\
\text { (Good) }\end{array}$ & Good \\
\hline
\end{tabular}

\section{B. Curriculum Implementation in the Aspects of Input}

The evaluation of curriculum implementation in terms of input aspect includes (1) completeness of the curriculum components; (2) facilities and infrastructure; (3) learning resources and aids; (4) educational personnel's.

TABLE II. IMPLEMENTATION OF CURRICULUM IN THE ASPECTS OF INPUT

\begin{tabular}{|c|c|c|c|c|c|c|}
\hline \multirow{2}{*}{ Curriculum } & \multicolumn{5}{|c|}{ Curriculum Implementation in the Aspect of Input: } & \multirow[t]{2}{*}{ Category } \\
\hline & Curriculum Tools & Facilities & $\begin{array}{c}\text { Learning Resources } \\
\text { and Media }\end{array}$ & $\begin{array}{l}\text { Educational } \\
\text { Personnels }\end{array}$ & Input & \\
\hline $\begin{array}{l}\text { Curriculum } \\
2006\end{array}$ & $\begin{array}{l}62,53 \\
\text { (Fair) } \\
\end{array}$ & $\begin{array}{l}63,65 \\
\text { (Fair) } \\
\end{array}$ & $\begin{array}{l}64,80 \\
\text { (Fair) } \\
\end{array}$ & $\begin{array}{l}61,60 \\
\text { (Fair) } \\
\end{array}$ & $\begin{array}{l}63,14 \\
\text { (Fair) } \\
\end{array}$ & Fair \\
\hline K-13 & $\begin{array}{l}62,60 \\
\text { (Fair) }\end{array}$ & $\begin{array}{l}60,75 \\
\text { (Fair) } \\
\end{array}$ & $\begin{array}{l}60,61 \\
\text { (Fair) } \\
\end{array}$ & $\begin{array}{l}60,80 \\
\text { (Fair) } \\
\end{array}$ & $\begin{array}{l}61,19 \\
\text { (Fair) }\end{array}$ & Fair \\
\hline
\end{tabular}

If it is viewed from the aspect of input, the implementation of the Curriculum 2006 and the K-13 have the same condition, which is categorized as Fair. It implies that there are still some weaknesses thus it is not optimal. This suggests that even though schools have shifted from the Curriculum 2006 to the $\mathrm{K}-13$, there has been no significant improvement in the input aspects, either from schools or related parties. If there is not improvement the input aspect, the graduates' competency will not be achieved as planned.

The curriculum tools, especially the syllabus, and the Lesson Plans should be fully provided. Syllabus is the outline of the description and the order of the material, as well as the direction of the learning implementation of each subject. Some vocational (productive) subjects are not adequately completed with syllabus. Even the Competency Standards of some vocational subjects have not been formally issued by The Ministry of Education and Culture. Teachers through the Teacher Working Groups attempt to develop Competency Standards, and Syllabus with reference to similar or related subjects, since some subjects in the K-13 still have similarities, with subjects in the curriculum 2006.

Facilities and infrastructure are very important in the learning process. The learning process in vocational schools requires the support of facilities and infrastructure that are more complex than learning in public schools. Availability of workshops, and laboratories in the field of expertise is an absolute requirement in the implementation of practical learning. The main weakness of laboratories or workshops in
VHS is the lack of qualified equipment, such as computer unit specifications, standard electric measurement equipment, electrical and control installation equipment, and electrical related equipment. Equipment in the workshops $\mathrm{pr}$ laboratories should always be updated in accordance with technological advances.

The textbooks and instructional media used in VHS have not been fully adapted to the K-13. Teacher generally still use textbooks which is used for the curriculum 2006. The Ministry of Education and Culture only provides new textbooks for non-vocational subjects. Most of the books used on productive subjects have not been developed specifically for the K-13. Learning media for the K-13 is not yet available. Some teachers are creative enough to search for interactive learning media with the media of internet.

Teachers are the most decisive factor in the success of a learning. Quantitatively, the number of VHS teachers included for productive subjects is sufficient. Nevertheless, the mastery of the subject matter and competence in the learning still needs to be improved. Many teachers still have not mastered the subject matter in the K-13. Technical guidance for vocational teachers who have been conducted more on the management of $\mathrm{K}-13$, while the material is still relatively limited. The number of teachers who have followed the technical guidance is also still limited. 
TABLE III. CURRICULUM IMPLEMENTATION OF IN THE ASPECT OF PROCESS

\begin{tabular}{|c|c|c|c|c|c|c|}
\hline \multirow{2}{*}{ Curriculum } & \multicolumn{5}{|c|}{ Curriculum Implementation in the Aspect of Process: } & \multirow{2}{*}{ Category } \\
\hline & $\begin{array}{c}\text { Curriculum } \\
\text { Management }\end{array}$ & $\begin{array}{l}\text { Learning } \\
\text { Activities }\end{array}$ & $\begin{array}{l}\text { Students' discipline } \\
\text { and creativity }\end{array}$ & $\begin{array}{l}\text { Teachers' } \\
\text { competency in } \\
\text { learning }\end{array}$ & Process & \\
\hline $\begin{array}{l}\text { Curriculum } \\
2006\end{array}$ & $\begin{array}{l}68,40 \\
\text { (Fair) }\end{array}$ & $\begin{array}{l}66,20 \\
\text { (Fair) }\end{array}$ & $\begin{array}{l}65,60 \\
\text { (Fair) }\end{array}$ & $\begin{array}{l}67,60 \\
\text { (Fair) }\end{array}$ & $\begin{array}{l}66,95 \\
\text { (Fair) }\end{array}$ & Fair \\
\hline K-13 & $\begin{array}{l}67,60 \\
\text { (Fair) }\end{array}$ & $\begin{array}{l}66,40 \\
\text { (Fair) }\end{array}$ & $\begin{array}{l}61,40 \\
\text { (Fair) }\end{array}$ & $\begin{array}{l}67,40 \\
\text { (Fair) }\end{array}$ & $\begin{array}{l}65,70 \\
\text { (Fair) }\end{array}$ & Fair \\
\hline
\end{tabular}

Curriculum Implementation in the aspect of process, both curriculum 2006 and K-13 have the same condition which is classified as Fair. Student discipline and creativity are the lowest of the three components in the process aspect. Learning activities are very important because the interaction of teachers with students, and between students is crucial in achieving competence. Weaknesses in learning activities include the dominant role of the teacher in learning even though the teacher has been trying to activate the students. Most students prefer listening, less active, and do not like to ask questions. In group practice lessons, only a few students are active in learning. Other students just watch, follow or just help. Student independence in learning is still poor. In addition, teachers' ability in learning management still needs to be improved. The lesson plan activities that have been prepared in the lesson plans should not be rigid, but adjusted to the conditions in which the lesson takes place.

\section{Curriculum Implementation in the Aspect of Product}

The Evaluation instrument of the implementation of the curriculum 2006 and the K-13 was in the form of questionnaires. The product aspect statement items consists of 20 items. The respondents consisted of teachers of VHS in Yogyakarta. The questionnaire grid consists of four variables. including (1) the students or graduates' competence; (2) the students' interest and (3) academic culture.

\begin{tabular}{|c|c|c|c|c|c|}
\hline \multirow{2}{*}{ Curriculum } & \multicolumn{4}{|c|}{ Curriculum Implementation in the Aspect of Product: } & \multirow{2}{*}{ Category } \\
\hline & $\begin{array}{c}\text { Students } \\
\text { Competency }\end{array}$ & $\begin{array}{c}\text { Students' Learning } \\
\text { Motivation }\end{array}$ & $\begin{array}{l}\text { Academic } \\
\text { Culture }\end{array}$ & Whole Product & \\
\hline $\begin{array}{l}\text { Curriculum } \\
2006\end{array}$ & $\begin{array}{l}68,05 \\
\text { (Fair) }\end{array}$ & $\begin{array}{l}67,45 \\
\text { (Fair) }\end{array}$ & $\begin{array}{l}68,40 \\
\text { (Fair) }\end{array}$ & $\begin{array}{l}67,96 \\
\text { (Fair) }\end{array}$ & Fair \\
\hline $\mathrm{K}-13$ & $\begin{array}{l}68,10 \\
\text { (Fair) }\end{array}$ & $\begin{array}{l}67,84 \\
\text { (Fair) }\end{array}$ & $\begin{array}{l}69,35 \\
\text { (Fair) }\end{array}$ & $\begin{array}{l}68,43 \\
\text { (Fair) } \\
\end{array}$ & Fair \\
\hline
\end{tabular}

Implementation of the curriculum in the aspect of product both curriculum 2006, and K-13 are categorized as Fair. The three components on the product aspect, namely the competence of the students or graduates, learning interests of the students, and academic culture are categorized as Fair. The students' competence was not be achieved optimally. This is consistent with the findings about the aspects of input and process.

Ideally, if the learning process, both theory and practice is successfully carried out and is supported by facilities, teaching materials and adequate media, it will achieve optimal learning achievement. The students' learning interest is not better than the learning achievement. Real interest in learning is very important for students to study harder, both during the learning process and beyond learning. Learning interest will prompt the student competence since the students' potency and learning activities are quite diverse. Based on the findings it reveals that the academic culture is also categorized as fair.
In general, academic culture in schools has not encouraged the students, the teachers and other educational staff to work and study hard. This is actually inversely proportional with the vision of a vocational school, which is generally characterized by excellence in achievement and character.

Implementation of the curriculum, including the K-13, should be preceded by the improvement of school management. The quality of academic culture of each citizen of the school needs to be further developed.

\section{E. Implementation of the Curriculum in the Aspect of Context, Input, Process, Product (CIPP)}

The result of data analysis shows that the input aspect of the $\mathrm{K}-13$ is categorized as good, while the other aspect shows a relatively similar result that is included in the fair category. This shows that the implementation of the curriculum 2006 and the K-13 still need a lot of improvement. 
TABLE V. THE CURRICUlum IMPLEMENTATION IN THE ASPECT OF CONTEXT, INPUT, PRocess, PRODUCT (CIPP)

\begin{tabular}{|c|c|c|c|c|c|c|}
\hline Curriculum & Context & Input & Proses & Produk & CIPP & Category \\
\hline Curriculum 2006 & 67,64 & 63,14 & 66,95 & 67,96 & 66,42 & Fair \\
& (Fair) & (Fair) & (Fair) & Fair) & (Fair) & Fair \\
\hline K-13 & 70,76 & 61,19 & 65,70 & 68,43 & 66,52 & (Fair) \\
& (Good) & (Fair) & (Fair) & (Fair) & \\
\hline
\end{tabular}

The aspects of the context of the K-13 are generally classified as good. However, there is still a need for improvement in order to better suit the goals of VHS, community needs, and the needs of the world of work. The improvements are essential to building a strong conceptual and substantial foundation of the K-13 thus, teachers and leaders of VHS become more optimistic in applying the K-13 according to the goals and functions of VHS and the needs of the world of work.

If the implementation of the $\mathrm{K}-13$ is supported with complete curriculum tools, facilities, adequate learning resources, and teachers who are competent in the implementation of learning, then students' learning outcomes will be optimal as expected. Nevertheless, the results of the study indicate that the learning outcomes and the students' learning interest as part of the product aspect are included in the fair category. The reasons are the aspects of input and process in the implementation of the curriculum which are categorized as fair.

Before establishing a new curriculum, an assessment should be conducted on the feasibility of resources, both human resources and supporting resources. Schools are not able to prepare the necessary resources (human resources and support facilities) due to relatively abrupt or hasty decision. Curriculum tools, especially syllabus and textbooks for VHS of Electricity Expertise Field are also not yet available. The Ministry of Education and Culture should set up a complete curriculum tool and distribute it to schools prior to curriculum implementation.

Based on these findings it is clear that The Ministry of Education and Culture has not set up curriculum tools and complete school facilities, including adequate teachers in the implementation of the $\mathrm{K}-13$. On the other hand, there is enforcement for schools to implement the K-13 despite not having enough preparation.

Table 5 generally reveals several unsuitable components in the K-13 because K-13 is a relatively new curriculum which is implemented in VHS less than three years. There are a lot of differences between the K-13 and the curriculum 2006, especially those that have implications on supporting facilities, mastery of teachers, and curriculum tools, as well as the process of learning and assessment.

\section{CONCLUSIONS}

In general, the implementation of the new curriculum, K13 in VHS has not appropriately conducted and has not achieved the expected results. The K-13 is not completely in line with the needs of the world of work, and the needs of society. Supporting facilities, human resources, and the process of implementation of learning and assessment, and management of the implementation of the new curriculum has not been organized properly so that the achievement of the new curriculum implementation results are not optimal. The introduction of a new curriculum is not better than the introduction of the previous curriculum, both with the support of resources, the implementation process, and the results.

Several factors are suspected to be the reasons of the unsuccessful implementation of the K-13, including inadequate curriculum tools, especially syllabus and textbooks, and operational guides; poor understanding of teachers and VHS leaders of a conceptual and practical aspect of the new curriculum; and inadequate laboratory and workshop facilities.

The curriculum changes should be equipped with adequate resource designs and supports. It is necessary to improve the curriculum from the framework and substance aspect to better suit the needs of the community and the world of work. Technical guidance on teachers and VHS leaders needs to be school-based and comprehensive. Laboratory and workshop improvements in VHS need to be conducted in accordance with the substance of the new curriculum. The Ministry of Education and Culture needs to publish operational guidance on the implementation of the K-13. The guidance should be complete, comprehensive, easy to be understood by all stakeholders, and not only include the implementation mechanisms but also detailed adjustment of competencies and materials to be provided in each semester, as well as the management of educational staffs in relation to the development of competence, career and welfare.

\section{REFERENCES}

[1] Andersson and Kopsen. Continuing Professional Development of Vocational Teachers: Participation in A Swedish Nasional Initiative. (http://creativecommons.org/licenses/by/4.0). 2015.

[2] Audu, Rufai., I.Y Umar, A.M Idris, "Facilities Provision and Maintenance: Necessity for Effective Teaching and Learning in Technical Vocational Education", IOSR Journal of Research \& Method in Education (IOSR- 
JRME) e-ISSN: 2320-7388, Volume 3, Issue 1 (Sep. Oct. 2013), PP 28-32 www.iosrjournals.org. 2013

[3] Badan Pusat Statistik. 2017. Pengangguran Terbuka Menurut Pendidikan Tertinggi yang Ditamatkan 1986 (https://www.bps.go.id/linkTabelStatis/view/id/972), 2017.

[4] Dorothy Spiller, Assessment: Feedback to Promote Student Learning. Hamilton New Zealand: Teaching Development Unit Wāhanga Whakapakari Ako Office of Deputy Vice-Chancellor Private Bag. (www.waikato.ac.nz/tdu), 2009.

[5] Education Services Australia, Preparing Secondary Students for Work. A framework for vocational learning and VET delivered to secondary students, 2014.

[6] Evelin Silla, Rita Siilivask, Ene Koitla, Reet Taimsoo, Innovation in Vocational Education and Training Estonia. Foundation Innove, Estonia, 2014.

[7] Fred C. Lunenburg, Theorizing about Curriculum: Conceptions and Definitions, 2011. International Journal Of Scholarly Academic Intellectual Diversity Volume 13, Number 1, 2011

[8] Heidi Andrade, Kristen Huff, and Georgia Brooke. Assessing Learning, 2012. Quincy, MA. Job for The Future. www.nmefoundation.org

[9] Instruksi Presiden Republik Indonesia No. 9 Tahun 2016 tentang Revitalisasi Sekolah Menengah Kejuruan dalam Rangka Peningkatan Kualitas dan Daya Saing Sumber Daya Manusia Indonesia, 2016.

[10] Israel, M., Ribuffo, C., \& Smith, S., "Universal Design for Learning: Recommendations for Teacher Preparation and Professional Development (Document No. IC-7)". Retrieved from University of Florida, Collaboration for Effective Educator, Development, Accountability, and Reform Center

(http://ceedar.education.ufl.edu/tools/innovationconfigurations/), 2014.

[11] Lucas Bill, Spencer Ellen, and Claxton Gay, How to Teach Vocational Education: A Theory of vocational pedagogy, City \& Guilds Centre for Skills Development.: London, United Kingdom, 2012.

[12] Marguerite Clarke.,What Matters Most for Student Assessment Systems: A Framework Paper, Washington DC: The International Bank for Reconstruction and Development/The WorldBank. (www.worldbank.org), 2012.

[13] Sandra Leaton Gray, David Scott and Euan Auld, Curriculum Development. A Report for the International Baccalaureate Organization (IBO) , Institute of Education, University of London, 2014.

[14] Shao-Wen Su, "The Various Concepts of Curriculum and the Factors Involved in Curricula-making", ISSN 17984769 Journal of Language Teaching and Research, Vol. 3, No. 1, pp. 153-158, 2012 ACADEMY PUBLISHER Manufactured in Finland. doi:10.4304/jltr.3.1.153-158. 2012, January 2012.

[15] The Danish Ministry of Education. Improving Vocational Education and Training- Overview of Reform of the Danish Vocational Education System, 2014.

[16] The Unesco International Bureau ff Education. Glossary of Curriculum Terminology,2013. 